\title{
Ebelik öğrencilerinin kendi kendine meme muayenesi ile ilgili bilgi ve tutumlarının belirlenmesi
}

\section{To determine the knowledge and attitude of midwifery students about breast self examination}

Saadet Gonca Mavi Aydoğdu', Zeliha Karapelit ${ }^{1}$

\section{öz}

AMAÇ: Bu çalışma, ebelik öğrencilerinin kendi kendine meme muayenesi ile ilgili bilgi ve tutumlarını belirlemek amacıyla yapılmıştır.

GEREÇ ve YÖNTEM: Tanımlayıcı nitelikte olan bu araştırmanın yapılabilmesi için etik kurul ve kurum onayı alınmıştır. Çalışma, Amasya Üniversitesi Sağlık Yüksekokulu ebelik bölümü öğrencileri ile gerçekleştirilmiştir (N=93). Veriler, 6-10 Şubat 2017 tarihleri arasında, araştırmacılar tarafından hazırlanan ve öğrencilerin sosyo-demografik özelliklerine ilişkin sorular ile kendi kendine meme muayenesine (KKMM) yönelik bilgi ve uygulamalarını içeren sorulardan oluşan soru formu aracılığı ile toplanmıștır. Araștırmadan elde edilen veriler SPSS 20 paket programı ile analiz edilmiştir. Gruplar arasındaki farklılıklar incelenirken Mann-Whitney U-Testi kullanılmış; nominal değişkenlerin grupları arasındaki ilişkiler incelenirken Ki-Kare analizi uygulanmıştır.

BULGULAR: Araştırmaya katılan öğrencilerin yaş ortalaması 20,42 22,01 olup, \%97,85'i bekârdır. Öğrencilerin \%77,42'si meme kanseri, \%76,34 ü ise kendi kendine meme muayenesi (KKMM) hakkında bilgi edindiğini belirtmesine rağmen, \%50,54’̈̈ KKMM yapmamaktadır. KKMM yapanların ise yalnızca \%30,43'ünün her ay yaptığı belirlenmiştir. Yani, öğrencilerin çoğunluğunun ( $\mathrm{N}=71)$ KKMM hakkında bilgisi olmasına rağmen, bunların yaklaşık üçte ikisi KKMM uygulamasını yapmamaktadır.

SONUC̣: Öğrencilerin KKMM hakkındaki bilgileri ve bu muayeneyi düzenli periyotlarla uygulama davranışları istenilen düzeyde değildir. Öğrencilerin KKMM'nin önemi ve nasıl yapıldığı hakkında bilgi düzeyleri, kendi sağlıklarına olan duyarlılıkları ve bu konudaki mesleki sorumluluğuna dair farkındalıkları arttırılmalıdır.

Anahtar Kelimeler: Öğrenci, ebelik, kendi kendine meme muayenesi

$\mathbf{M}$ eme kanseri, kadınlardaki insidansı ve mortalite hızı giderek artan bir kanser türüdür. ${ }^{[1]}$ Her sekiz kadından biri yaşamı boyunca meme kanseri ile karşılaşabilir. ${ }^{[2]}$ Ülkemizdeki Sağlık İstatistikleri Yıllığı 2014 verilerine göre, meme kanseri 2010 yılında kadınlarda \%22,9 oranıyla en sık görülen kanserdir. ${ }^{[3]}$

'Amasya Üniversitesi Sağılk Yüksekokulu, Ebelik Bölümü, Amasya

Yazışma Adresi / Correspondence:

Saadet Gonca Mavi Aydoğdu

Amasya Üniversitesi Sağlık Yüksekokulu İpekköy Yerleşkesi 05100 Amasya, Türkiye

Tel. $\quad+903582181-767$

E-mail: goncamavi38@gmail.com

Gelis / Received: $\quad 31.07 .2017$

Kabul / Accepted: 07.08.2017

\section{ABSTRACT}

OBJECTIVE: This study was carried out to determine the knowledge and attitude of the midwifery students on the self-examination of the breast. MATERIAL and METHODS: Ethical committee and institutional approval have been obtained in order to be able to carry out this research in a descriptive manner. The study was carried out in Amasya University School of Health with midwifery students $(\mathrm{N}=93)$. The data were collected from 6th to 10th of February 2017 by questionnaires consisting the socio-demographic characteristics of the students, and applications about breast self examination (BSE) prepared by searching through the literature. Analysis was performed with the SPSS 20 statistical software. The Mann-Whitney U-Test was used to examine the differences between groups; chi-square analysis was performed while examining groups of nominal variables.

RESULTS: The average age of students taking part in this research was $20.42 \pm 2.01 \%$, and $97.85 \%$ of them were bachelor. Although $77.42 \%$ of the students stated that they have information about breast cancer and $76.34 \%$ of them learn about breast self examination (BSE), $50.54 \%$ do not perform BSE. Only $30.43 \%$ of those who made BSE were found to have done it every month. That means, although the majority of the students $(\mathrm{N}=71)$ have knowledge about the BSE, about two-thirds do not apply the BSE.

CONCLUSION: It was seen that the students' knowledge about BSE and the habits of regularly doing this examination were not at the desired level. Students should be aware of the importance of BSE and how it is done; awareness of their own health and their professional responsibilities should be increased.

Keywords: Student, midwifery, breast self-examination

Meme sağlığına ilişkin veriler, özellikle gelişmekte olan ülkelerde meme kanserine bağlı mortalite ve morbidite oranlarının artışta olduğunu göstermektedir. ${ }^{[4]}$ Beklenen yaşam süresinin uzaması, stresörlerin ve obezitenin artısı, ilk gebelik yaşının ilerlemesi ve paritenin azalması gibi predispozan faktörler nedeniyle, önümüzdeki yıllarda meme kanseri görülme oranının daha da artacağı tahmin edilmektedir. ${ }^{[5]}$ Evrensel bir sorun olan meme kanseri, sağılı alanındaki gelişmelere, erken tanı ve tedavi olanaklarındaki değişimlere, sağlık riskleri konusunda toplumsal duyarlılığın artmasına rağmen, kadınların yaşamını önemli ölçüde tehdit etmektedir. ${ }^{[6]}$

Memede benign değişimler, ailesel/genetik yatkınlık, ileri yaş gebeliği, ovarial fonksiyonlar, endokrin nedenler, erken 
menarş, geç menopoz, otuz yaş sonrası ilk doğum, nullipar olma ve emzirme süresi meme kanserinin gelişiminde önemli risk faktörleridir. Ayrıca, sigara/alkol kullanımının ve yüksek yağlı diyet ile beslenmenin de meme kanserinin gelişiminde rol oynadığı düşünülmektedir. ${ }^{[7]}$

Meme kanseri, bilinenin aksine, son yıllarda daha erken yaşlarda bile görülür. Bu nedenle, çok genç yaşlarda meme kanserinden korunma, erken tanı ve tedavi hakkında kadınları bilgilendirmek hayatî önem taşır. ${ }^{[8]}$

Erken tanı, meme kanserinde sağlığın korunması/geliştirilmesi, hastalık ve ölüm oranlarının azaltılması ve yaşam kalitesinin yükseltilmesinde en etkili yöntemdir. ${ }^{[9-11]}$ Meme kanserinden mutlak koruyucu bir yöntem olmadığı için, hastalığın prognozu ve sağkalım açısından erken tanı oldukça önemlidir. ${ }^{[12]}$ Erken tanıda başarıya ulaşabilmek için, hedef kitlenin erken tanının önemine inanması, farkındalığının arttırılması ve bilgisinin davranışa dönüştürülmesi gerekir. ${ }^{[6]}$

Meme kanserinde erken tanı için "Kendi Kendine Meme Muayenesi” (KKMM), "Klinik Meme Muayenesi” (KMM) ve "Mamografi" (MG) önerilen ve birbirini tamamlayan üç yöntemdir. KKMM'nin 20 yaşından itibaren ayda bir kez menstruasyonun 5.-7. günü, menopoz sonrası ise her ayın aynı gününde yapılması gerekir. Amerikan Kanser Derneği (ACS); kadınlara 20 yaşından itibaren aylık KKMM, 2040 yaş arasında üç yılda bir KMM ve 40 yaşından itibaren KMM ve MG'nin klinik bulgu aranmaksızın yıllık yapılmasını önermektedir. ${ }^{[2,9,13,14]}$

Tanı yöntemlerindeki gelişmelere rağmen, memedeki kitlelerin büyük çoğunluğu kadınların kendileri tarafından fark edilmekte ve bu kitlelerin dörtte birinin malignensi olduğu bilinmektedir. ${ }^{[13,15]} \mathrm{Bu}$ nedenle, her ay düzenli olarak KKMM yapan kadın, meme dokusundaki en ufak değişikliği erken dönemde fark edecek ve zaman kaybetmeden tedavi edilmesine katkıda bulunacaktır. Bu durum ise meme kanserinde sağkalım oranını arttıracaktır. ${ }^{[11]}$

KKMM, her kadının uygulayabileceği, fazla zaman ve işgücü gerektirmeyen, masrafsız bir uygulamadır. ${ }^{[16]}$ KKMM, memenin gözle ve palpasyonla muayenesini içerir. Memenin gözle muayenesinde sırasıyla, kollar iki yanda, yukarı kaldırılarak ve sırt kaslarını germek amacıyla ellerin kalçada olduğu pozisyonlarda meme incelenir. Bu gözlem esnasında meme başı çöküklüğü, meme başında akıntı, memelerde asimetri, meme cildinde portakal kabuğu görünümü gibi şüpheli bulgularda sağlık personeline başvurulması önerilir. ${ }^{[7]}$ Memenin palpasyon ile muayenesinde amaç kitle tespitidir ve göğüs duvarının yassılaşması için sırtüstü yatılarak, muayene edilecek memenin altına yastık konulur ve içten dışa doğru dairesel hareketlerle meme dokusu incelenir. ${ }^{[14]}$
Ülkemizdeki meme kanseri vakalarında, kitlelerin ilk olarak kadının kendisi tarafından belirlendiği göz önünde bulundurulduğunda, kadınlara verilecek eğitimlerin ne kadar önemli olduğu görülmektedir. ${ }^{[17]}$ Yapılan çalışmalar, kadınların erken tanı uygulamaları hakkındaki bilgisizliği, ulaşım imkânlarının yetersizliği, sosyal desteğinin olmayışı, eğitimsizlik, cinsiyet eşitsizliği gibi engellerin meme kanserinde erken tanıyı geciktirdiğini göstermektedir. ${ }^{[9]}$

Son yıllarda artış gösteren meme kanserine ilişkin genç kadınların farkındalığını arttırmak, taramalar konusunda kadınları bilinçlendirmek ve sağlığını geliştirme davranışları kazanmalarını sağlamak oldukça önemlidir. ${ }^{[1]}$ Toplumda rol-model olan ebelerin meme kanserinin tarama yöntemlerini bilme ve uygulama konusunda donanımlı olmaları beklenirken, ülkemizde yapılan araştırmalar onların bu konuda yetersiz olduklarını göstermektedir. ${ }^{[12]}$

Bu çalışmayla, ebelik öğrencilerinin KKMM hakkındaki bilgi ve tutumlarını ölçmek, bu konuda yeterli olabilmeleri için planlanan eğitimlere yön verebilmek amaçlanmıştır.

\section{GEREÇ ve YÖNTEM}

Tanımlayıcı nitelikteki bu çalışma, ebelik öğrencilerinin KKMM ile ilgili bilgi ve tutumlarını belirlemek amacıyla yapılmıştır. Araştırmanın evrenini bir üniversitenin ebelik bölümü öğrencileri oluşturmaktadır. Araştırmada örneklem seçimine gidilmemiş, öğrencilerin tümü araştırma kapsamına alınmıştır ( $N=93)$. Veriler, 6-10 Şubat 2017 tarihleri arasında araştırmacılar tarafından, literatür taranarak geliştirilen ve öğrencilerin sosyo-demografik özelliklerine ilişkin sorular (yaş, sınıf, medeni durum gibi) ile KKMM'ye yönelik bilgi ve uygulamalarını içeren sorulardan oluşan (ailede meme kanseri hikayesi, KKMM bilme durumu, KKMM yapma durumu, KKMM yapma sıklığı gibi) soru formu aracılığı ile toplanmıştır. Araştırmanın uygulanabilmesi için etik kurul ve kurum izni alınmıştır. Soru formu uygulanmadan önce öğrencilere araştırmanın amacı açıklanmış ve onam formu okutularak sözel onamları alınmıştır.

\section{İstatistiksel analiz}

Araştırmadan elde edilen veriler SPSS 20 paket programı (IBM, New York, ABD) kullanılarak analiz edilmiştir. Değişkenlerin normal dağılımdan gelme durumları araştırılırken, birim sayıları nedeniyle Shapiro Wilk's testinden yararlanılmıştır. Gruplar arasındaki farklılıklar incelenirken, değişkenlerin normal dağılımdan gelmemesi nedeniyle Mann-Whitney U-Testi kullanılmıştır. Nominal değişkenlerin grupları arasındaki ilişkiler incelenirken ki-kare analizi uygulanmıştır. " $2 \times 2$ " tablolarda, gözelerdeki beklenen değerlerin yeterli 
hacme sahip olmaması durumlarında Fisher's Exact Test kullanılmış olup, " $\mathrm{R} \times \mathrm{C}$ ” tablolarda Monte Carlo Simülasyonu yardımıyla Pearson ki-kare analizi uygulanmıştır.

\section{Araștırmanın sınırlılıkları}

Araştırmanın küçük bir örneklem grubunda yapılması araştırmanın sınırlılığı olarak değerlendirilmektedir.

\section{BULGULAR}

Araştırmaya katılan öğrencilerin yaş ortalaması 20,42 $\pm 2,01$ yıl olup, \%97,85'i bekârdır. Öğrencilerin \%27,96'sı 1. sınıf, $\% 21,51$ 'i 2. sinıf, \%20,43'ü 3. sinıf ve \%30,11'i 4. sinıftan- dır; \% 15,05’i sigara ve \%3,23’ü alkol kullanmaktadır. Öğrencilerin ilk menarş yaşı $13,33 \pm 1,22$ yıl olarak bulunmuştur.

Öğrencilerin \%77,42'si meme kanseri, \%76,34'ü ise KKMM hakkında bilgi edindiğini belirtmesine rağmen, \%50,54’ü KKMM yapmamaktadır. KKMM yapmayanların \%47,73'ü bilmediğini, \%40,91'i meme kanseri için risk taşımadığını düşündüğünü, \%18,18'i kötü bir sonuç alma endişesi yaşadığını, \%4,55’i zamanının olmadığını ve \%4,55'i unuttuğunu ifade etmiştir. KKMM yapanların ise yalnızca \%30,43’ünün her ay yaptığı belirlenmiştir.

Öğrencilerin KKMM ile ilgili çoktan seçmeli bilgi sorularına verdikleri yanıtlar incelendiğinde; \%8,89’u “KK-

Tablo 1. Öğrencilerin *KKMM ile ilgili bilgi sorularına verdikleri yanıtların dağılımı

\begin{tabular}{|c|c|c|c|}
\hline Bilgi Soruları & & $n$ & $\%$ \\
\hline \multirow{5}{*}{$\begin{array}{l}\text { KKMM uygulamasına kaç } \\
\text { yaşında başlanmalıdır? }\end{array}$} & İlk adeti gördükten sonra & 60 & 66,67 \\
\hline & 18 yaşında & 16 & 17,78 \\
\hline & 20 yaşında & 8 & 8,89 \\
\hline & 30 yaş ve üzerinde & 6 & 6,67 \\
\hline & Toplam & 90 & 100 \\
\hline \multirow{5}{*}{$\begin{array}{l}\text { KKMM uygulaması ne sıklıkla } \\
\text { yapılmalıdır? }\end{array}$} & Aklıma geldikçe & 4 & 4,44 \\
\hline & Her banyodan sonra & 29 & 32,22 \\
\hline & Ayda bir defa & 55 & 61,11 \\
\hline & Yılda bir defa & 2 & 2,22 \\
\hline & Toplam & 90 & 100 \\
\hline \multirow{5}{*}{$\begin{array}{l}\text { Adet gören bir kadın ayın } \\
\text { hangi döneminde KKMM } \\
\text { uygulamalıdır? }\end{array}$} & Adetin ilk günü & 7 & 7,87 \\
\hline & Adetin başlamasından 5-7 gün sonra & 30 & 33,71 \\
\hline & Adetin bitiminden 5-7 Gün Sonra & 45 & 50,56 \\
\hline & Herhangi bir gün & 7 & 7,87 \\
\hline & Toplam & 89 & 100 \\
\hline \multirow{5}{*}{$\begin{array}{l}\text { Menopoz sonrası KKMM } \\
\text { ne zaman yapılmalıdır? }\end{array}$} & Her banyodan sonra & 29 & 32,22 \\
\hline & Ayda bir kez rastgele & 6 & 6,67 \\
\hline & Her ayın belirli bir gününde & 52 & 57,78 \\
\hline & Yılda bir kez & 3 & 3,33 \\
\hline & Toplam & 90 & 100 \\
\hline \multirow[t]{5}{*}{ KKMM en doğru nasıl yapılır? } & Her iki memenin ayna karşısında sadece gözle incelenmesiyle & 1 & 1,11 \\
\hline & Her iki memenin ayna karşısında sadece elle dokunulmasıyla & 0 & 0 \\
\hline & $\begin{array}{l}\text { Her iki memenin herhangi bir günde bir ayna karşısında gözle incelenmesi ve elle } \\
\text { dokunulmasıyla }\end{array}$ & 4 & 4,44 \\
\hline & $\begin{array}{l}\text { Her iki memenin her ayın belirli bir gününde düzenli olarak ayna karşısında gözle } \\
\text { incelenmesi ve elle dokunulmasıyla }\end{array}$ & 85 & 94,44 \\
\hline & Toplam & 90 & 100 \\
\hline \multirow{5}{*}{$\begin{array}{l}\text { KKMM uygulanırken en uygun } \\
\text { el tekniği nedir? }\end{array}$} & Avuç içi dairesel hareket & 5 & 5,62 \\
\hline & Avuç içi ile dikey hareket & 0 & 0 \\
\hline & Tüm el ile dairesel hareket & 6 & 6,74 \\
\hline & Üç parmak ile dairesel ya da dikey hareket & 78 & 87,64 \\
\hline & Toplam & 89 & 100 \\
\hline
\end{tabular}

*KKMM: Kendi Kendine Meme Muayenesi 
MM'ye 20 yaşında başlanmalıdır”, \%61,11'i “ayda bir defa KKMM uygulanmalıdır”, \%33,71'i “âdetin başlamasından 5-7 gün sonra KKMM yapılmalıdır”, \%57,78’i "menopoz sonrası her ayın belirli bir gününde KKMM yapılmalıdır”, \%94,44’ü “KKMM her iki memenin her ayın belirli bir gününde düzenli olarak ayna karşısında gözle incelenmesi ve elle dokunulmasıyla yapılmalıdır", \%87,64'ü "KKMM üç parmak tekniğiyle dairesel ya da dikey hareketlerle yapılmalıdır” diyerek doğru yanıt vermiştir (Tablo 1).

Öğrencilerin bilgi sorularından aldıkları toplam puan $55,2 \pm 21,98$ olarak tespit edilmiştir. Beklenen düzeyde olmayan bu sonuç, öğrencilerin KKMM'nin önemi, uygulaması ve halk sağlığında eğitimi konusunda eksik olduklarının göstergesidir. Toplam bilgi puanı ile sınıflar arasında istatistiksel olarak anlamlı bir farklılık vardır $(\mathrm{p}=0,047)$. Sınıf düzeyi arttıkça toplam yüzdelik puan da doğrusal olarak artmıştır (Tablo 2). Meme kanseri ve KKMM hakkında bilgi edinme durumlarına göre bilgi puan ortalamaları karşılaştırıldığında, 2. sınıftan itibaren Fizik Muayene ve Hasta Tanılama Yöntemleri, Kadın
Sağlığı ve Hastalıkları, Jinekolojik Onkoloji ve Entegre dersleri kapsamında meme kanseri ve KKMM ile ilgili bilgi edinenlerin bilgi puan ortalamalarının daha yüksek olduğu belirlenmiştir. Ailede meme kanseri öyküsü ve KKMM yapma durumlarına göre bilgi puan ortalamaları karşılaştırıldığında, istatistiksel olarak anlamlı bir farklılık bulunmamıştır ( $\mathrm{p}=0,754)$ (Tablo 3).

Öğrencilerin, âdet gören bir kadının ayın hangi döneminde KKMM uygulaması gerektiğini bilme durumları ile meme kanserine ilişkin bilgi edinme durumları arasında istatistiksel olarak anlamlı bir fark bulunmuştur $(\mathrm{p}=0,023)$. Meme kanseri hakkında bilgi edinenlerin \%38,89'u bu soruyu doğru yanıtlarken, \%61,11'i yanlış yanıt vermiştir (Tablo 4).

Menopoz sonrası KKMM'nin ne zaman yapılması gerektiğine ilişkin bilgi durumları ile meme kanseri hakkında bilgi edinme durumları arasında istatistiksel olarak anlamlı bir ilişki bulunmaktadır ( $\mathrm{p}=0,009)$. Meme kanseri hakkında bilgi edinenlerin \%63,89'u bu soruyu doğru yanıtlarken, \%36,11'i yanlış yanıt vermiştir (Tablo 4).

Tablo 2. Öğrencilerin sınıf düzeylerine göre bilgi puan ortalamalarının karşılaştırılması

\begin{tabular}{|c|c|c|c|c|c|c|c|c|c|c|}
\hline & & \multicolumn{6}{|c|}{ Toplam Bilgi Puanı } & \multicolumn{3}{|c|}{ Kruskal Wallis H Testi } \\
\hline & & $n$ & Mean & Median & Min & $\operatorname{Max}$ & ss & Sira Ort. & $H$ & $p$ \\
\hline \multirow{5}{*}{ Sınıfinız } & 1.sınıf & 26 & 45,51 & 41,67 & 0 & 83,33 & 26,06 & 36,81 & \multirow{4}{*}{7,931} & \multirow{5}{*}{0,047} \\
\hline & $2 . \sin ı f$ & 20 & 54,17 & 50 & 33,33 & 66,67 & 13,11 & 44,8 & & \\
\hline & 3.sınıf & 19 & 57,89 & 50 & 16,67 & 100 & 25,68 & 48,97 & & \\
\hline & 4.sinıf & 28 & 63,1 & 66,67 & 16,67 & 83,33 & 17,19 & 56,7 & & \\
\hline & Toplam & 93 & 55,2 & 50 & 0 & 100 & 21,98 & \multicolumn{2}{|r|}{$1-4$} & \\
\hline
\end{tabular}

Tablo 3. Öğrencilerin meme kanseri ve kendi kendine meme muayenesine ilişkin bilgi puan ortalamalarının karşılaştırılması

\begin{tabular}{|c|c|c|c|c|c|c|c|c|c|c|}
\hline & & \multicolumn{6}{|c|}{ Toplam Bilgi Puanı } & \multicolumn{3}{|c|}{ Mann Whitney U Testi } \\
\hline & & $n$ & Mean & Median & Min & Max & ss & Sira Ort. & $z$ & $p$ \\
\hline \multirow{3}{*}{$\begin{array}{l}\text { Meme kanseri hakkında bilgi } \\
\text { edinme durumu }\end{array}$} & Evet & 72 & 60,19 & 66,67 & 16,67 & 100 & 20,09 & 52,73 & & \\
\hline & Hayır & 21 & 38,1 & 33,33 & 0 & 66,67 & 19,82 & 27,36 & $-3,883$ & 0,001 \\
\hline & Toplam & 93 & 55,2 & 50 & 0 & 100 & 21,98 & & & \\
\hline \multirow{3}{*}{$\begin{array}{l}\text { KKMM hakkında bilgi edinme } \\
\text { durumu }\end{array}$} & Evet & 71 & 60,09 & 66,67 & 16,67 & 100 & 19,82 & 52,58 & & \\
\hline & Hayır & 22 & 39,39 & 33,33 & 0 & 83,33 & 21,54 & 28,98 & $-3,672$ & 0,001 \\
\hline & Toplam & 93 & 55,2 & 50 & 0 & 100 & 21,98 & & & \\
\hline \multirow[t]{3}{*}{ KKMM yapma durumu } & Evet & 46 & 59,78 & 66,67 & 16,67 & 100 & 22,1 & 52,09 & & \\
\hline & Hayır & 47 & 50,71 & 50 & 0 & 83,33 & 21,13 & 42,02 & $-1,842$ & 0,065 \\
\hline & Toplam & 93 & 55,2 & 50 & 0 & 100 & 21,98 & & & \\
\hline \multirow{3}{*}{$\begin{array}{l}\text { Ailede meme kanseri bulunma } \\
\text { durumu }\end{array}$} & Evet & 9 & 59,26 & 50 & 33,33 & 100 & 23,73 & 49,61 & & \\
\hline & Hayır & 84 & 54,76 & 50 & 0 & 100 & 21,89 & 46,72 & $-0,313$ & 0,754 \\
\hline & Toplam & 93 & 55,2 & 50 & 0 & 100 & 21,98 & & & \\
\hline
\end{tabular}

*KKMM: Kendi Kendine Meme Muayenesi 
Tablo 4. Öğrencilerin meme kanseri hakkında bilgi edinme durumlarına göre bilgi sorularına verdikleri yanıtların karşılaştırılması

\begin{tabular}{|c|c|c|c|c|c|c|c|c|c|}
\hline & & \multicolumn{6}{|c|}{ Meme Kanseri Hakkında Bilgi Edinme Durumu } & \multirow{2}{*}{\multicolumn{2}{|c|}{ Ki Kare Testi }} \\
\hline & & \multicolumn{2}{|c|}{ Evet } & \multicolumn{2}{|c|}{ Hayır } & \multicolumn{2}{|c|}{ Toplam } & & \\
\hline & & $n$ & $\%$ & $n$ & $\%$ & $n$ & $\%$ & Ki Kare & $p$ \\
\hline \multirow{3}{*}{$\begin{array}{l}\text { KKMM'nin hangi yaşta yapılacağını } \\
\text { bilme durumu }\end{array}$} & YANLIŞ & 65 & 90,28 & 20 & 95,24 & 85 & 91,4 & \multirow{3}{*}{ Fisher'sexact } & \multirow{3}{*}{0,678} \\
\hline & DOĞRU & 7 & 9,72 & 1 & 4,76 & 8 & 8,6 & & \\
\hline & Toplam & 72 & 100 & 21 & 100 & 93 & 100 & & \\
\hline \multirow{3}{*}{$\begin{array}{l}\text { KKMM'nin hangi sıklıkta yapılacağını } \\
\text { bilme durumu }\end{array}$} & YANLIŞ & 26 & 36,11 & 12 & 57,14 & 38 & 40,86 & \multirow{3}{*}{2,169} & \multirow{3}{*}{0,141} \\
\hline & DOĞRU & 46 & 63,89 & 9 & 42,86 & 55 & 59,14 & & \\
\hline & Toplam & 72 & 100 & 21 & 100 & 93 & 100 & & \\
\hline \multirow{3}{*}{$\begin{array}{l}\text { Adet gören bir kadında KKMM’nin ne } \\
\text { zaman yapılacağını bilme durumu }\end{array}$} & YANLIŞ & 44 & 61,11 & 19 & 90,48 & 63 & 67,74 & \multirow{3}{*}{5,142} & \multirow{3}{*}{0,023} \\
\hline & DOĞRU & 28 & 38,89 & 2 & 9,52 & 30 & 32,26 & & \\
\hline & Toplam & 72 & 100 & 21 & 100 & 93 & 100 & & \\
\hline \multirow{3}{*}{$\begin{array}{l}\text { Menopoz sonrası KKMM'nin ne zaman } \\
\text { yapılacağını bilme durumu }\end{array}$} & YANLIŞ & 26 & 36,11 & 15 & 71,43 & 41 & 44,09 & \multirow{3}{*}{6,856} & \multirow{3}{*}{0,009} \\
\hline & DOĞRU & 46 & 63,89 & 6 & 28,57 & 52 & 55,91 & & \\
\hline & Toplam & 72 & 100 & 21 & 100 & 93 & 100 & & \\
\hline \multirow{3}{*}{$\begin{array}{l}\text { KKMM'nin nasıl uygulanacağını bilme } \\
\text { durumu }\end{array}$} & YANLIŞ & 3 & 4,17 & 5 & 23,81 & 8 & 8,6 & \multirow{3}{*}{ Fisher'sexact } & \multirow{3}{*}{0,013} \\
\hline & DOĞRU & 69 & 95,83 & 16 & 76,19 & 85 & 91,4 & & \\
\hline & Toplam & 72 & 100 & 21 & 100 & 93 & 100 & & \\
\hline \multirow{3}{*}{$\begin{array}{l}\text { KKMM'nin doğru palpasyon tekniğini } \\
\text { bilme durumu }\end{array}$} & YANLIŞ & 8 & 11,11 & 7 & 33,33 & 15 & 16,13 & \multirow{3}{*}{ Fisher'sexact } & \multirow{3}{*}{0,037} \\
\hline & DOĞRU & 64 & 88,89 & 14 & 66,67 & 78 & 83,87 & & \\
\hline & Toplam & 72 & 100 & 21 & 100 & 93 & 100 & & \\
\hline
\end{tabular}

*KKMM: Kendi Kendine Meme Muayenesi

Tablo 5. Öğrencilerin KKMM hakkında bilgi edinme durumlarına göre bilgi sorularına verdikleri yanıtların karşılaştıılması

\begin{tabular}{|c|c|c|c|c|c|c|c|c|c|}
\hline & & \multicolumn{6}{|c|}{ KKMM Hakkında Bilgi Edinme Durumu } & \multirow{2}{*}{\multicolumn{2}{|c|}{ Ki Kare Testi }} \\
\hline & & \multicolumn{2}{|c|}{ Evet } & \multicolumn{2}{|c|}{ Hayır } & \multicolumn{2}{|c|}{ Toplam } & & \\
\hline & & $n$ & $\%$ & $n$ & $\%$ & $n$ & $\%$ & Ki Kare & $p$ \\
\hline \multirow{3}{*}{$\begin{array}{l}\text { KKMM'nin hangi yaşta yapılacağını bilme } \\
\text { durumu }\end{array}$} & YANLIŞ & 65 & 91,55 & 20 & 90,91 & 85 & 91,4 & & \\
\hline & DOĞRU & 6 & 8,45 & 2 & 9,09 & 8 & 8,6 & Fisher'sexact & 1 \\
\hline & Toplam & 71 & 100 & 22 & 100 & 93 & 100 & & \\
\hline \multirow{3}{*}{$\begin{array}{l}\text { KKMM'nin hangi sıklıkta yapılacağını } \\
\text { bilme durumu }\end{array}$} & YANLIŞ & 23 & 32,39 & 15 & 68,18 & 38 & 40,86 & & \\
\hline & DOĞRU & 48 & 67,61 & 7 & 31,82 & 55 & 59,14 & 7,842 & 0,006 \\
\hline & Toplam & 71 & 100 & 22 & 100 & 93 & 100 & & \\
\hline \multirow{3}{*}{$\begin{array}{l}\text { Adet gören bir kadında KKMM'nin ne zaman } \\
\text { yapılacağını bilme durumu }\end{array}$} & YANLIŞ & 44 & 61,97 & 19 & 86,36 & 63 & 67,74 & & \\
\hline & DOĞRU & 27 & 38,03 & 3 & 13,64 & 30 & 32,26 & 3,525 & 0,06 \\
\hline & Toplam & 71 & 100 & 22 & 100 & 93 & 100 & & \\
\hline \multirow{3}{*}{$\begin{array}{l}\text { Menopoz sonrası KKMM’nin ne zaman } \\
\text { yapılacağını bilme durumu }\end{array}$} & YANLIŞ & 28 & 39,44 & 13 & 59,09 & 41 & 44,09 & & \\
\hline & DOĞRU & 43 & 60,56 & 9 & 40,91 & 52 & 55,91 & 1,895 & 0,169 \\
\hline & Toplam & 71 & 100 & 22 & 100 & 93 & 100 & & \\
\hline \multirow{3}{*}{$\begin{array}{l}\text { KKMM'nin nasıl uygulanacağını bilme } \\
\text { durumu }\end{array}$} & YANLIŞ & 2 & 2,82 & 6 & 27,27 & 8 & 8,6 & & \\
\hline & DOĞRU & 69 & 97,18 & 16 & 72,73 & 85 & 91,4 & Fisher'sexact & 0,002 \\
\hline & Toplam & 71 & 100 & 22 & 100 & 93 & 100 & & \\
\hline \multirow{3}{*}{$\begin{array}{l}\text { KKMM'nin doğru palpasyon tekniğini } \\
\text { bilme durumu }\end{array}$} & YANLIŞ & 8 & 11,27 & 7 & 31,82 & 15 & 16,13 & & \\
\hline & DOĞRU & 63 & 88,73 & 15 & 68,18 & 78 & 83,87 & Fisher'sexact & 0,041 \\
\hline & Toplam & 71 & 100 & 22 & 100 & 93 & 100 & & \\
\hline
\end{tabular}

*KKMM: Kendi Kendine Meme Muayenesi 
KKMM'nin nasıl uygulanacağını bilme durumları ile meme kanseri hakkında bilgi edinme durumları arasında istatistiksel olarak anlamlı bir ilişki bulunmaktadir $(\mathrm{p}=0,013)$. Meme kanseri hakkında bilgi edinenlerin \%95,83'ü bu soruyu doğru yanıtlarken, \%4,17'si yanlış yanıt vermiştir (Tablo 4).

KKMM'nin doğru palpasyon tekniğini bilme durumları ile meme kanseri hakkında bilgi edinme durumları arasında istatistiksel olarak anlamlı bir ilişki bulunmaktadir $(\mathrm{p}=0,037)$. Meme kanseri hakkında bilgi edinenlerin \%88,89'u bu soruyu doğru yanıtlarken, \%11,11'i yanlış yanıt vermiştir (Tablo 4).

KKMM uygulamasının ne sıklıkla yapılacağını bilme ile KKMM hakkında bilgi edinme durumları arasında istatistiksel olarak anlamlı bir ilişki bulunmaktadır $(\mathrm{p}=0,006)$. KKMM hakkında bilgi edinenlerin \%67,61'i bu soruyu doğru yanıtlarken, \%32,39’u yanlış yanıt vermiştir (Tablo 5).

KKMM'nin nasıl uygulanacağını bilme ile KKMM hakkında bilgi edinme durumları arasında istatistiksel olarak anlamlı bir ilişki bulunmaktadır ( $\mathrm{p}=0,002)$. KKMM hakkında bilgi edinenlerin \%97,18'i bu soruyu doğru yanıtlamıştır (Tablo 5).

KKMM'nin doğru palpasyon tekniğini bilme ile KKMM hakkında bilgi edinme durumları arasında istatistiksel olarak anlamlı bir ilişki bulunmaktadır $(p=0,41)$. KKMM hakkında bilgi edinenlerin \%88,73'ü bu soruyu doğru yanıtlarken, \%11,27'si yanlış yanıt vermiştir (Tablo 5).

\section{TARTIȘMA}

Yapılan çalışmalar, sigara kullanımının meme kanserine yakalanma riskini arttırdığını göstermektedir. Alkol kullanımının ise meme kanserine etkisi halen tartışmalı olmakla birlikte, yapılan çalışmalar, alkol alımı miktarına paralel olarak meme kanseri riskinde artış olduğunu göstermektedir. ${ }^{[18]}$ Çalışmamızda, öğrencilerin sigara kullanım oranları düşük bulunmuştur ve neredeyse hiçbiri alkol kullanmamaktadır.

Çalışmamızda, öğrencilerin \%9,68'inde ailede meme kanseri öyküsü mevcuttur. Ailesinde meme kanseri öyküsü olan öğrencilerin KKMM'ye ilişkin bilgi sorularındaki puan ortalamalarının yüksek olması beklenmesine karşın, anlamlı bir fark bulunmamıştır. Benzer şekilde, Gençtürk'ün ${ }^{[12]}$ sağlık profesyonelleri üzerinde yaptığı çalışma bulgularımızı desteklemektedir.

Ülkemizdeki bazı çalışmalar, kadınların büyük bir bölümünün meme muayenesini uygulamadığını göstermiştir. Aynı şekilde, kadınların meme muayenesi yapma konusundaki isteksizliklerinin, bir kitle bulma ve bu durumda ne yapacağını bilememe korkusu ile ilişkili olduğu, meme muayenesi hakkındaki bilgilerinin yeterli olmadığı ve bu durumun eğitimle azaltılabileceği bildirilmektedir. ${ }^{[17]}$ Benzer şekilde, çalışmamızda da öğrencilerin yarısı KKMM yapmamaktadır. Öğrenciler, KKMM yapmama nedenlerini; meme muayenesini bilmemeleri, meme kanseri için risk taşımadığını düşünmeleri, kötü bir sonuç alma endişesi, zamanlarının olmaması veya unutmaları olarak göstermişlerdir. Segni ve arkadaşları ${ }^{[18]}$ ortalama yaşları 22,9 yıl olan üniversite öğrencisinden oluşan 368 olguyu inceledikleri çalışmada, KKMM'nin uygulanma oranını düşük bulmuş (\%44,2), bunun nedenlerini öğrencilerin KKMM'nin nasıl yapıldığını bilmemeleri ve kendilerini sağlıklı görmeleri olarak belirtmişlerdir. Krepia ve arkadaşlarının ${ }^{[19]}$ toplamda 175 hemşirelik öğrencisinin bilgi ve tutumlarını inceledikleri çalışmalarında, öğrencilerin sadece \%10'unun periyodik olarak KKMM yaptığı ve bu öğrencilerde uygulamaya ilişkin ciddiyet ve yarar algısının yüksek çıktı̆̆ı saptanmıştır.

Çalışmamızda, KKMM bilgi düzeyi ile KKMM'nin uygulanması arasında paralel bir ilişki tespit edilmiştir, fakat KKMM yapan öğrencilerin çoğunluğunun $(\% 52,17)$ aklına geldikçe yaptığı, yalnızca \%30,43'ünün her ay yaptığı belirlenmiştir. Sevindik ve arkadaşları ${ }^{[20]} 283$ olgudan oluşan çalışmalarında, öğrencilerin KKMM uygulama oranını sonuçlarımızla benzer bulurken (\%55,5), KKMM'yi düzenli periyotlarla yapanların oranını bizim çalışmamıza göre daha yüksek $(\% 56,7)$ bulmuşlardır. Lavdaniti' nin ${ }^{\text {[21] }}$ hemşire öğrencilerle yaptığı çalışmada, öğrencilerin KKMM bilgisine sahip oldukları fakat yeterli ve düzenli yapmadıkları tespit edilmiştir.

Çalışmamızda, öğrencilerin öğrenim gördükleri sınıflara göre KKMM yapma durumları incelendiğinde, sınıf düzeyine paralel olarak KKMM yapma oranlarının yükseldiği görülmüştür. Gök Özer ve arkadaşlarının ${ }^{[22]}$ yaptıkları çalışmada, hemşirelik öğrencilerinin son sınıflara doğru meme kanseri ve meme muayenesine dair bilgi ve uygulamalarının arttığı, özellikle dördüncü sınıf öğrencilerinin bilgi ve uygulamalarının en yüksek düzeyde olduğu belirlenmiştir. Gündoğan ve arkadaşları ${ }^{[23]}$ ise, üst sınıflarda alt sınıflara kıyasla güven/öz-etkinlik oranlarının arttığını, bunun KKMM'ye olan yarar algısı ve uygulamasına eğilimi etkilediğini saptamışlardır. Bu sonuçlar, KKMM'nin ilerleyen sınıflarda ders içeriğine eklenmesiyle beraber, bilgi düzeyinin artması ve uygulamanın öneminin kavranmasından kaynaklanıyor olabileceğini düşündürmektedir.

Öğrencilerin KKMM hakkında bilgi edinme durumlarına göre bilgi düzeyleri yüksek bulunsa da, KKMM'ye hangi yaşta başlanacağı, adet gören kadında ne zaman yapılacağı 
ile ilgili olan sorulara çoğunluğunun yanlış yanıt verdiği görülmüştür. Bu durumun sebebi olarak, alt sınıflardaki öğrencilerin KKMM hakkındaki bilgi yetersizlikleri gösterilebilir. KKMM ile ilgili diğer bilgi sorularına yanıtların doğruluk oranının yüksek çıkmasında, bu öğrencilerin rastlantısal ya da eksik bilgileriyle verdikleri doğru yanıtların etkisi olduğu düşünülmektedir.

Ülkemizde yapılan çalışmalarda, kadınların meme kanserine ilişkin tarama yöntemlerini yeterince kullanmadığı ve meme kanseri hakkında yeterince bilgi sahibi olmadıkları belirlenmiştir. ${ }^{[24]}$ Çalışmamızda, ebelik öğrencilerinin KKMM ile ilgili bilgi sorularından aldıkları puan ortalamalarının istenen düzeyde olmadığı $(55,2 \pm 21,98)$ görülmüştür. Bu sonuç, öğrencilerin mesleki farkındalığının ve sağlık algı düzeylerinin yeterli olmadığını düşündürmektedir.

\section{SONUÇ Ve ÖNERILER}

Ülkemizde ebelerin, birinci basamak sağlık hizmetlerinin yürütülmesinde çoğunluk olarak aktif rol almaları nedeniyle, erken tanı için risk gruplarının belirlenmesi, tarama programlarının uygulanması ve sağlığı koruma/geliştirme davranışlarının benimsenmesi için sağlık eğitimin yapılması alanlarında önemli görevleri bulunmaktadır. KKMM gibi koruyucu sağlık hizmetlerinde önemli rolü olan ebelerin, mesleki bilgi ve uygulama becerisinin en üst düzeyde olması gerekmektedir.

Sonuç olarak, öğrencilerin KKMM'ye ilişkin bilgi düzeylerinin öğrenim gördükleri sınıfa paralel olarak artış gösterdiği, ancak istenen düzeyde olmadığı görülmüş-

\section{KAYNAKLAR}

1. Özen B, Zincir H, Erten ZK. Özkan F. Elmalı F. Genç kadınların meme kanseri ve kendi kendine meme muayenesi konusunda bilgi ve tutumları ile sağlıklı yaşam biçimi davranışları. Eur J Breast Health 2013;9:200-4. doi: 10.5152/tjbh.2013.33

2. Başak F. Konya ili, bozkır ilçesinde meme kanseri tarama ile ilgili bilgi ve davranışların değerlendirilmesi, kesitsel anket çalışması. Bezmialem Science 2016;1:19-24. doi: 10.14235/bs.2015.674

3. https://saglik.gov.tr/TR/dosya/1-101702/h/yilliktr.pdf Erişim: 25.10.2016

4. Seçginli S. Meme kanseri taraması: son yenilikler neler? TAF Prev Med Bull 2011;10:193-200.

5. Kolutek R, Avcı İA. Eğitim ve evde izlemin, evli kadınların meme ve serviks kanseri ile ilgili bilgi düzeylerine ve uygulamalarına etkisi. J Breast Health 2015;11:155-62. doi: 10.5152/tjbh.2015.2647

6. Akyolcu N, Uğraş GA. Kendi kendine meme muayenesi: erken tanıda ne kadar önemli? J Breast Health 2011;7:10-4.

7. Alpteker H, Avcı A. Kırsal alandaki kadınların meme kanseri bilgisi ve kendi kendine meme muayenesi uygulama durumlarının belirlenmesi. J Breast Health 2010;6:74-9. tür. Öğrencilerin yalnızca yarısının, yapanların içinde ise \%30,43'ünün her ay düzenli olarak KKMM yaptığı belirlenmiştir. KKMM yapmayanların yarısı, sebep olarak bilmiyor olmalarını göstermişlerdir.

Araştırmanın sonuçları doğrultusundaki önerilerimiz şunlardır:

- KKMM yapmayan öğrencilerin kendi sağlıklarına ilişkin ciddiyet algısını etkileyen faktörler çok boyutlu olarak araştırılmalıdır.

- KKMM uygulamasında, anormal bulguya rastlama endişesi, uygulamanın zaman alması gibi engeller, verilecek eğitimlerle aşılmalı ve öğrencilerin sağlığı koruma ve geliştirmede etkili olan sağlık inançları ve öz-etkinlikleri arttırılmalıdır.

- Bunun yanında, öğrencilerin mesleki sorumlulukları$\mathrm{n} ı$ istenen düzeyde yerine getirebilmeleri için, KKMM hakkındaki gerekli olan ayrıntılı teorik ve uygulama bilgileri arttırılmalıdır.

- Öğrencilerde bu konudaki mesleki bilincin artması için, meme kanserinin kadın sağlığı üzerindeki fiziksel, psikolojik sosyal etkileri ve erken tanı/tedavinin önemi kavratılmalıdır.

\section{Çıkar çatıșması ve finansal destek}

Yazımızın tarafsızlı̆̆ı ile ilgili bilinmesi gereken herhangi bir mali katkı veya diğer çıkar çatışma ihtimali (potansiyeli) ve ilişki alanı yoktur.

8. Koçyiğit O, Erel S, Kısmet K, Kılıçoğlu B, Sabuncuoğlu MZ, Akkuş MA. Polikliniğe başvuran kadınların meme kanseri, meme muayenesi ve mamografi hakkında bilgi düzeyi. Nobel Med 2011;7:19-25.

9. Ersin F, Bahar Z. Sağlığı geliştirme modellerinin meme kanseri erken tanı davranışlarına etkisi: bir literatür derlemesi. DEUHYO ED 2012;5:28-38.

10. Beydağ KD, Karaoğlan H. Kendi kendine meme muayenesi eğitiminin öğrencilerin bilgi ve tutumlarına etkisi. Kor Hek 2007;6:106-11.

11. Kipay SS, Seki Z, Tabak RS. Öğretmenlere uygulanan meme kanserinde farkındalık eğitiminin etkililiği. Sağlık ve Toplum 2013;23:1:32-8.

12. Gençtürk N. Kadın sağlık profesyonellerinin meme kanseri erken tanı yöntemlerini bilme ve uygulama durumları. J Breast Health 2013;9:5-9.

13. Göçgeldi E, Açıkel CH, Hasde M, Aygut G, Çelik S, Gündüz İ, Karadeniz Y, Ayas R, Şahin E, Deniz C. Ankara-Gölbaşı ilçesinde bir grup kadının kendi kendine meme muayenesi yapma konusundaki tutum ve davranışlarının belirlenmesi. Fırat Tip Dergisi 2008;13:261-5. 
14. Taşkın L. Doğum ve Kadın Sağlığı Hemşireliği, 13. baskı. Ankara: Nobel Tip Kitabevi; 2014. s.692.

15. Alpteker H, Gümüş D, Doğan S, Bilir S, Önal M. Kız öğrencilerin meme kanseri ve kendi kendine meme muayenesi bilgi ve uygulamalarının incelenmesi. J Breast Health 2011;7:176-81.

16. Gürsoy AA. Kendi kendine meme muayenesi çelişkisi. TAF Prev Med Bull 2008;7:257-60.

17. Koç Z, Sağlam Z. Kadınların meme kanseri, koruyucu önlemler ve kendi kendine meme muayenesi ile ilgili bilgi ve uygulamalarının belirlenmesi ve eğitimin etkinliği. J Breast Health 2009;5:25-33.

18. Segni MT, Tadesse DM, Amdemichael R, Demissie HF. Breast self-examination: knowledge, attitude, and practice among female health science students at Adama Science and Technology University, Ethiopia. Gynecol Obstet (Sunnyvale) 2016;6:368. doi:10.4172/2161-0932.1000368

19. Sapountzi-Krepia D, Releiti M, Lavdaniti M, Psyhoqiou M, Choliou M, Xenofontos M, Savva M. Evaluating female nursing students' knowledge and attitudes regarding breast self-examination. Health Care Women Int 2017:1-10. doi: $10.1080 / 07399332.2017 .1326921$
20. Sevindik F, Çelebi Ö, Öner Öİ, Oğuzöncül F. Hemşirelik ve ebelik öğrencilerinin meme kanserine ilişkin risk faktörleri ve kendi kendine meme muayenesi ile ilişkili bilgi ve davranışları. E-Journal of New World Sciences Academy 2011;6:4B0003.

21. Lavdaniti. Perceptions and health beliefs of Greek nursing students about breast self-examination: A descriptive study. International Journal of Nursing Practice 2015;21:882-8. doi: 10.1111/ ijn. 12323

22. Gök Özer F, Taşçı Beydağ KD, Özbay C. Hemşirelik öğrencilerinin meme kanseri hakkındaki bilgileri ve meme muayenesini uygulama durumları. Pamukkale Tip Dergisi 2009:2:15-9.

23. Gündoğan D, Akın S, Durna Z, Şirin A. Hemşirelik öğrencilerinin kendi kendine meme muayenesine ilişkin tutum ve inançlarının değerlendirilmesi. Sağlık ve Toplum 2012;22:23-37.

24. Keten HS, Yıldırım F, Ölmez S, Üçer H. Çelik M. Kahramanmaraş Kanser Erken Teşhis Tarama ve Eğitim Merkezi'ne başvuran kadınların meme kanseri konusunda bilgi, tutum ve davranışları. Gaziantep Med J 2014; 20:212-6. doi: 10.5455/GMJ-30-154373 